\title{
Processing of Polymeric Dosage Forms for Advanced Drug Delivery: From Melt-Extrudates to Nanoparticles
}

\author{
Eric Doelker*, Ugo Bilati, Cun An Nguyen, Sergio Galindo-Rodriguez, and Abraham G. Sarraf
}

\begin{abstract}
Pharmaceutical technology has been directed towards solving the challenges brought by changes in drug discovery characterized by the advent, on the one hand, of sparingly water-soluble drugs exhibiting low oral bioavailability and, on the other, by the so-called biopharmaceuticals, namely peptide and protein drugs as well as nucleic acid materials. The article reviews some of the results obtained in the laboratory in connection with oral and parenteral drug delivery. Hot-melt extrudates for oral administration appear to be very efficient for the sustained release of highly water-soluble drugs, whereas $\mathrm{pH}$-sensitive nanoparticles have proved very beneficial for increasing the bioavailability of protease inhibitors. Special attention is also paid to the scaling up aspect of the nanoparticle preparation methods. As for the parenteral route, biodegradable implants and nanoparticles are examined for their potential to extend drug action. The important issue of premature degradation of peptide or protein drugs during manufacturing of particles is also addressed using tetracosactide and insulin as model drugs. In this respect, emphasis is put on the use of MALDI-TOF MS for the direct assessment of the primary structure of proteins such as insulin in nanoparticles and simultaneous quantification. Finally, various means for preventing rapid clearance of colloidal carriers from the bloodstream by the reticuloendothelial system are described, in particular the utilization of pegylated biodegradable polymers. The reduction of nanoparticle phagocytosis opens perspectives for improved drug targeting of organs.
\end{abstract}

Keywords: Controlled drug release · Drug delivery systems · Drug targeting · Extrudates · Hot-melt extrusion · Implants $\cdot$ Microparticles $\cdot$ Nanoparticles $\cdot$ Oral route $\cdot$ Parenteral route $\cdot$ Pellets

\section{Introduction}

As has always been the case, recent advances in dosage forms have been aimed at optimizing the delivery of intact drugs at the site of absorption or action. Pharmaceutical technology has also been directed towards solving the challenges brought by the evolution of drug discovery, characterized in particular by the advent of two types of ac-
${ }^{\star}$ Correspondence: Prof. E. Doelker School of Pharmaceutical Sciences Ecole de Pharmacie Genève-Lausanne University of Geneva

Quai Ernest-Ansermet 30

$\mathrm{CH}-1211$ Geneva 4

Tel.: +41223796148

Fax: +4122 3796567

E-Mail: eric.doelker@pharm.unige.ch tive compounds. On one hand, drug design approaches based on combinatorial chemistry and quantitative structure-activity relationships have led to new highly lipophilic and less water-soluble chemicals exhibiting low oral bioavailability [1][2]. On the other hand, recent advances in genomics and proteomics have given impetus to the development of the so-called biopharmaceuticals, i.e. peptides and proteins, including vaccines and monoclonal antibodies, as well as nucleic acids, including antisense nucleotides [3]. The present article will review some of the findings of the authors in the field of dosage forms for oral (melt-extrudates, nanospheres) and parenteral (implants, microparticles, nanoparticles) drug delivery.

\section{Oral Drug Delivery}

\section{Extrudates for Sustained Drug Delivery}

Extrusion of wet masses is a standard procedure in drug product manufacturing. Alternatively, hot melt extrusion - a technique broadly used in polymer engineering
- has been considered in the pharmaceutical field rather recently for the preparation of sustained release dosage forms and of solid dispersions, aimed at prolonging the duration of the pharmaceutical action, increasing the drug bioavailability or reducing the side effects [4-6]. We evaluated the potential advantage of this integrated technology (often referred to as a single-step process) for producing pellets with sustained release of highly dosed freely soluble drugs [7][8]. Formulations varying in terms of polymers, plasticizers, additives, drug loading, and processing conditions were produced using a ram or a screw extruder. Stability, morphology, porosity, and drug release were examined. Formulations based on EVAC $\left(\right.$ Elwax $\left.^{\circledR}\right)$ and a polymethacrylate derivative (Eudragit RSPM $^{\circledR}$ ) containing up to $50 \%$ drug could be extruded under smooth conditions. Fig. 1 shows the release profiles of diltiazem hydrochloride in $\mathrm{pH} 7.0$ phosphate buffer from $50 \%$ drug-loaded pellets $(2 \times 2 \mathrm{~mm})$ containing various additives. The latter were included with the aim of increasing the release rate through their porosigenic effect on pellets and also to reduce burst release by taking advantage 
of their viscosifying effect upon dissolution in water. Such non-coated pellets could be filled into capsules.

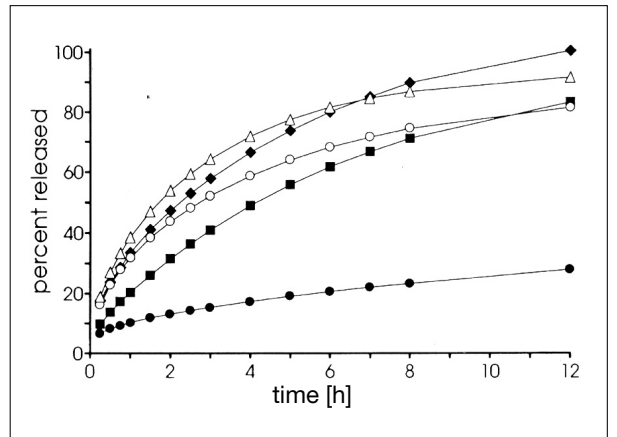

Fig. 1. Release profiles at $\mathrm{pH} 7.0$ of diltiazem hydrochloride from EVAC-based pellets containing $20 \%$ of various swelling agents. Key: - Ac-Di-Sol ${ }^{\circledR} ;$ Explotab ${ }^{\circledR} ;$; crospovidone; $\triangle$ low-substituted hydroxypropylcellulose; $\bullet$ no additive [8]

A more recent and fundamental work addresses polymer structure orientation during hot-melt extrusion [9] and non-uniform drug distribution in extrudates produced on an instrumented capillary rheometer [10]. As a result apparent zero order drug release was observed. Polymer orientation in the extrudates is apparent in the atomic force image shown in Fig. 2. Orientation of polymer is parallel to the direction of extrusion and is pronounced in the peripheral layer (up to $200 \mu \mathrm{m}$ from the outer surface). A periodic distance of around $60 \mathrm{~nm}$ was measured between the oriented microfibrils using atomic force microscopy and confirmed by transmission electron microscopy.

\section{Nanoparticles for Increased Bioavailability}

The potential of $\mathrm{pH}$-sensitive nanoparticles to increase the oral bioavailability of poorly water-soluble, hydrophobic compounds has been examined in mice and dogs [11-14]. Different anti-infective agents

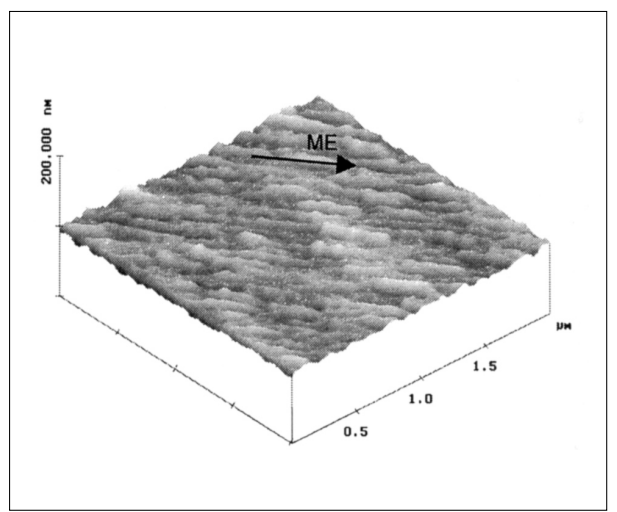

Fig. 2. Atomic force image showing Eudragit ${ }^{\circledR}$ RSPO microfibril orientation in the direction of molding extrusion (ED) [10] were incorporated in nanoparticles made of Eudragit $^{\circledR}$ L100-55. This poly(methacrylic acid-co-ethyl acrylate) is soluble above $\mathrm{pH}$ 5.5. The nanoparticles, of the matrix type [15], were prepared using the so-called emulsification-diffusion method [11][16][17]. One of the drugs tested was HIV-1 protease inhibitor CGP 70726 (Novartis) exhibiting a peptidomimetic structure with a molecular mass of 689.9. Its n-octanol-pH 7.4 phosphate buffer $\log \mathrm{P}$ value is 4.77 and it is almost insoluble in aqueous media $(0.12$ $\mathrm{mg} / \mathrm{l}$ at $\mathrm{pH} 6.2$ [13]). The nanoparticles were drug-loaded at $20 \%$ and had a diameter of ca. $300 \mathrm{~nm}$. In parallel, microparticles of the same composition but with a diameter of $c a .10 \mu \mathrm{m}$ were prepared using a spraydrying procedure to look at the effect of particle size. Both matrix-type particles were administered to fasted and fed dogs (Fig. 3 ). The formulations resulted in substantial absorption of CGP 70726, considering that when this drug was administered as an aqueous suspension, the plasma levels were below the quantification limit of the analytical method (data not shown). Maximum plasma concentration $\left(\mathrm{C}_{\max }\right)$ and bioavailabilities $\left(\mathrm{AUC}_{0-8 \mathrm{~h}}\right)$ were approximately twice as high for nanoparticles than for microparticles. No food effect was observed, except for nanoparticles in fed dogs $\left(\mathrm{t}_{\max }\right.$ of $1 \mathrm{~h}$ instead of 2). The positive results obtained can be ascribed to the combination of the high specific surface area of these particles, especially the nanoparticles, the high dissolution rate of the drug when molecularly dispersed or in an amorphous state and finally the rapid release of the drug close to the expected absorption window.

A major concern related to drug product manufacturing is, of course, the possibility of scaling up laboratory-scale technologies. Thus, a very recent study was dedicated to a comparative scaling up of three methods for producing ibuprofen-loaded nanoparticles, i.e. the salting-out, emulsification-diffu-

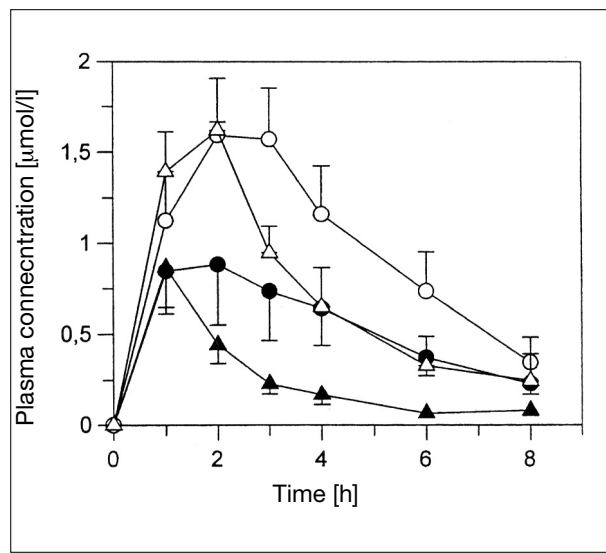

Fig. 3. Plasma concentration profiles of CGP 7076 after oral administration of Eudragit ${ }^{\circledR}$ L10055 nanoparticles $(\triangle, \boldsymbol{\Delta})$ and microparticles $(\bigcirc$, -) into fasted dogs $(\triangle, \bigcirc)$ and fed $\operatorname{dogs}(\mathbf{\Lambda}, \bullet)$; mean+/-s.e.m. $(n=4)[13]$ sion and nanoprecipitation procedures. The volume treated was increased from $60 \mathrm{ml}$ to 1.51 . Fig. 4 is an example of a batch of Eudragit $^{\circledR}$ L100-55 nanoparticles $(280 \mathrm{~nm}$ mean size) loaded with $9 \%$ ibuprofen and prepared using the so-called salting out method [18].

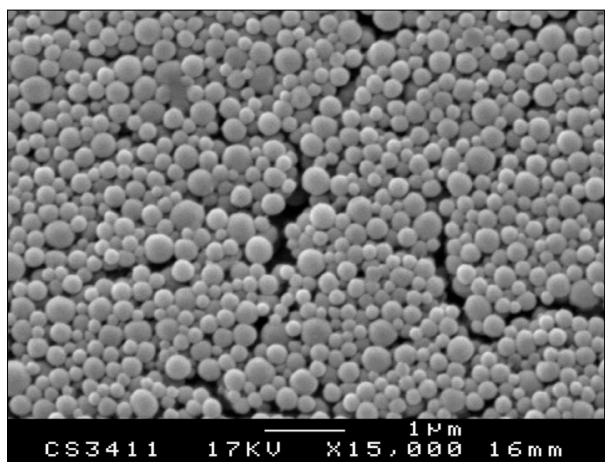

Fig. 4. Scanning electron micrograph of Eudragit ${ }^{\circledR}$ RSPO nanoparticles loaded with $9 \%$ ibuprofen [18]

\section{Parenteral Drug Delivery}

\section{Implants and Nanoparticles for Extended Drug Release}

Implants are usually aimed at prolonging drug action over days to years. We thus prepared cylindrical $(1 \times 10 \mathrm{~mm})$ implants using a ram extruder [19]. A new class of biocompatible polypeptide made of partially esterified glutamic acid named POMEG was used. Progesterone or fentanyl citrate was incorporated in various POMEG copolymers [19-21]. For instance, high fentanyl plasma levels were observed for about three days following insertion of a $25 \%$ drug-loaded implant in the rat gluteal muscle. Such POMEG implants demonstrated adequate biocompatibility (Fig. 5).

Biodegradable nanoparticles have been also used as a means to extend the action of drugs administered parenterally. The prolonged release properties of DL-PLA nanoparticles loaded with savoxepine were assessed in rats [22]. Plasma concentrations after intravenous (i.v) and intramuscular (i.m.) administration of nanoparticles loaded with the radiolabelled neuroleptic drug were almost superimposed and were sustained during the seven recorded days (Fig. 6). As a comparison, for the savoxepine in solution, less than one day was necessary to eliminate the same amount of radioactivity.

\section{Encapsulation of Peptide and Protein Drugs}

A major problem faced when incorporating peptide or protein drugs is the risk of their premature degradation during manu- 


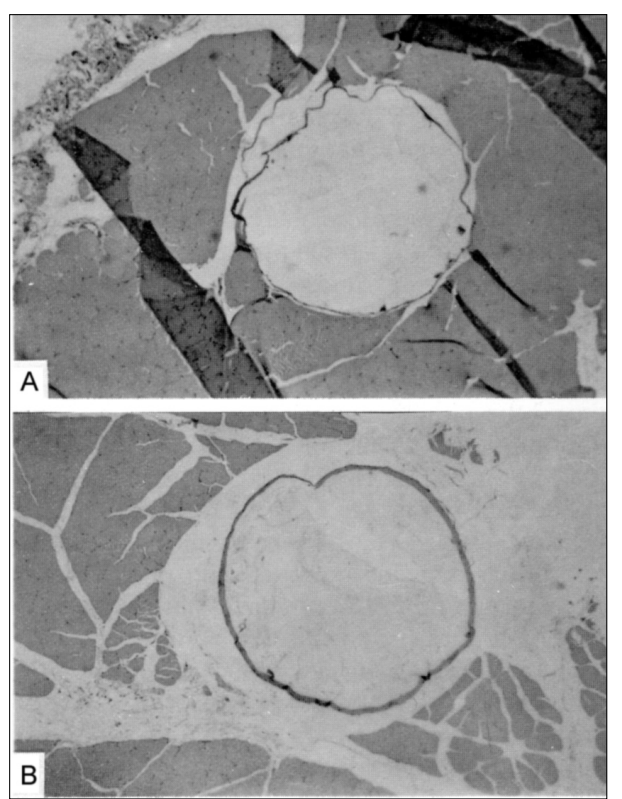

Fig. 5. Progesterone-loaded POMEG implant after implantation for 1 (A) and 6 (B) months in the rat gluteal muscle. The implant is still intact and well localized, surrounded with a very fine (A) to medium (B) collagen capsule. No inflammatory cells can be identified and the adjacent muscle is always normal [21].

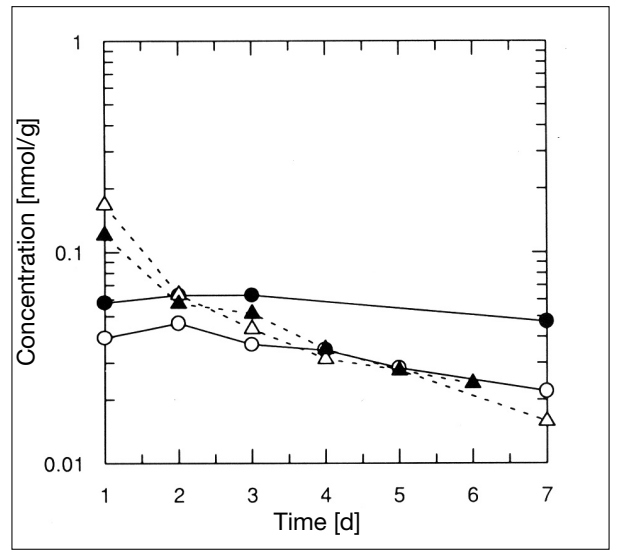

Fig. $6 .{ }^{14} \mathrm{C}$ plasma concentrations in rats after injection of a solution of ${ }^{14} \mathrm{C}$-savoxepine methanesulfonate i.v. $(\mathbf{\Delta})$ and i.m. $(\Delta)$ and of $\mathrm{C}^{14}$ savoxepine-loaded DL-PLA nanoparticles i.v. $(\bullet)$ and i.m. (O). Concentrations were normalized to a dose of $6 \mu \mathrm{mol}$ savoxepine base $/ \mathrm{kg}$ savoxepine [22].

facturing or in vitro drug release testing of the dosage form, during storage of the latter and possibly during the in vivo release phase following administration. The preparation method of the samples for analytical purpose (extraction, hydrolysis of the polymeric carrier) can also be problematic. This aspect was addressed using tetracoactide (Synacten ${ }^{\circledR}$ ) as model drug incorporated in biodegradable microspheres prepared from PCL, P(HB/HV), L-PLA and PLGA [23-25]. Microspheres were manufactured using different methods. As an example Fig. 7 shows L-PLA microspheres prepared using the so-called aerosol solvent extrac- tion system (ASES) with supercritical $\mathrm{CO}_{2}$. Tetracosactide, a polypeptide composed of the first 24 amino acids of ACTH, is subject to both oxidation and hydrolysis. The Table summarizes the tetracosactide degradation patterns following manufacturing of microspheres using three different methods [24]. Degradation of the polypeptide appears to depend on both the polymer and the manufacturing method used.

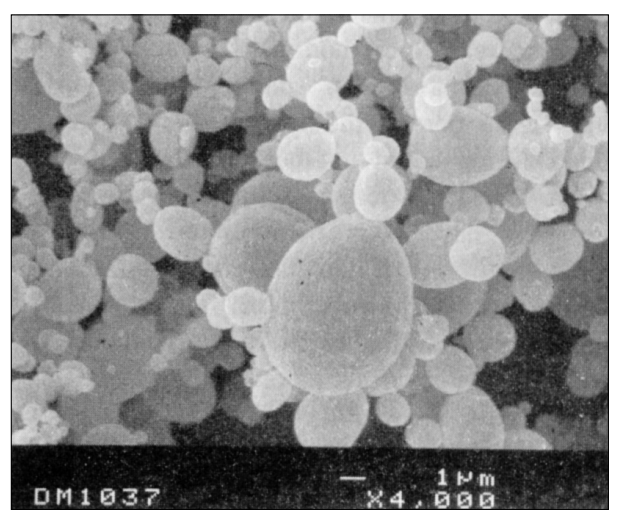

Fig. 7. Scanning electron micrograph of $1 \%$ tetracosactide loaded L-PLA microparticles prepared using the aerosol solvent extraction system [25]

The stability issue of this type of drug was also addressed with respect to nanoparticles. This was part of a study addressing the challenge of developing methods to encapsulate highly hydrophilic compounds [26-27]. The stability of biopharmaceuticals incorporated in PLGA nanoparticles was studied with insulin in particular. In this respect, it has been shown that matrix-assisted laser desorption/ionization time-of-flight (MALDI-TOF) mass spectrometry could be used for the direct assessment of the primary structure of entrapped insulin and for simultaneous quantification [28-29]. Only traces of insulin dimer were observed after nanoparticle manufacturing using MALDI-TOF MS, whereas about $3.3 \%$ A21 desamido insulin were present as measured by liquid chromatography with UV detection.

\section{Nanoparticles for Improved \\ Site-specific Drug Delivery}

Adequate therapy sometimes necessitates the drug to be delivered at a specific site of absorption or action. Drug targeting is often achieved using colloidal systems including liposomes, microemulsions, macromolecular complexes and nanoparticles. However, colloidal carriers, when intravenously injected, are rapidly detected as foreign bodies and quickly cleared from the blood circulation by the action of the reticuloendothelial system (or mononuclear phagocytic systems MPS), encompassing both tissular macrophages (in particular the liver with its Kupffer cells and the spleen) and monocytes circulating in the bloodstream. As a result nanoparticles are extensively taken up by the liver (up to $90 \%$ ) and the spleen (2-5\%) within minutes following injection. Phagocytosis of foreign bodies such as nanoparticles by macrophages involves, first, their attachment to macrophages mediated through the serum proteins called opsonins and, second, the ingestion of the particle. This extensive uptake of drug-loaded nanocarriers can be of clinical interest to treat cancerous or infectious diseases affecting for instance the liver. However, often sites other than organs of the MPS are targeted. The use of amphiphilic coating agents capable of modifying the surface characteristics of the colloidal carriers in order to delay or reduce their clearance by the MPS has opened new perspectives for improved drug targeting of various organs.

In this respect, internalization of biodegradable nanoparticles by human mononuclear phagocytic cells and its prevention has been the subject of several studies in the laboratory [30-34]. Incubation of a cell suspension and of a suspension of nanoparticles made fluorescent by incorporation of Nile red was performed in phosphate buffer, plasma and in serum. The cell-associated fluorescence was determined using flow cytometry. Various technological or chemical ways to reduce opsonization were investigated:

- coating DL-PLA nanoparticles by poly(ethylene glycols) [30][31],

Table. Percentages of intact tetracosactide, oxidised tetracosactide, and other degradation products in PLA and PLGA biodegradable microspheres prepared using spray-drying, a double emulsion solvent evaporation method (W/O/W) and the aerosol solvent extraction system (ASES) (1\% nominal drug loading) [24]

\begin{tabular}{lllll} 
Polymer or copolymer & $\begin{array}{l}\text { Method of pre- } \\
\text { paration }\end{array}$ & $\begin{array}{l}\% \text { intact } \\
\text { tetracosactide }\end{array}$ & $\begin{array}{l}\text { \% oxidised } \\
\text { tetracosactide }\end{array}$ & $\begin{array}{l}\text { \% other degra- } \\
\text { dation products }\end{array}$ \\
\hline DL-PLGA 50-50 & Spray-drying & 93.2 & 3.1 & 3.8 \\
L-PLA & W/O/W & 94.2 & 1.2 & 4.6 \\
DL-PLGA 75-25 & W/O/W & 88.2 & $\sim 0$ & 11.8 \\
DL-PLGA 50-50 & W/O/W & 82.5 & 4.2 & 13.4 \\
L-PLA & ASES & 93.8 & 3.4 & 2.8
\end{tabular}


- preparation of nanoparticles using PLA: PEO diblock and triblock copolymers [32][33],

- preparation of nanoparticles using PLAMePEG [34].

Fig. 8 compares the cellular uptake of PLA:PEO (MW 2000 to 10000) diblock and triblock copolymers as well as PEO-coated nanoparticles relative to non-coated particles. The best protective effect was found for PLA-PEO 5000 nanoparticles. Simple PEO adsorption at the particle surface has also some effect. In plasma, the uptake followed the same pattern as in serum, but with a different intensity, possibly because of inhibition of the complement system by EDTA in plasma. Prevention of the recognition of the particles by the MPS cells can be ascribed to both hydrophilization of the relatively hydrophobic surface of common PLA nanoparticles with regard to opsonin adsorption and to steric stabilization of this type of nanoparticle. Recently, we synthesized a novel fluorescent DL-PLA (DL-PLA end-capped with 1-pyrenebutanol), permitting the preparation of tagged nanoparticles when mixed with PLA [35].

As an application of surface-modified nanoparticles, coating of DL-PLA nanoparticles with PEG 20000 loaded with a photoactivable sensitizer $\left(\mathrm{ZnPCF}_{16}\right)$ was shown to significantly increase their blood circulation time and consequently their tumor accumulation in mice [36][37]. Consequently, nanoparticle formulation improved photodynamic therapy response of the tumor.

Pharmaceutical technology is, in essence, dedicated to respond to the challenges of drug therapy. Various dosage forms - in particular nanoparticles - represent promising drug delivery systems for increasing bioavailability of poorly soluble drugs, for extending the pharmacological action of drugs

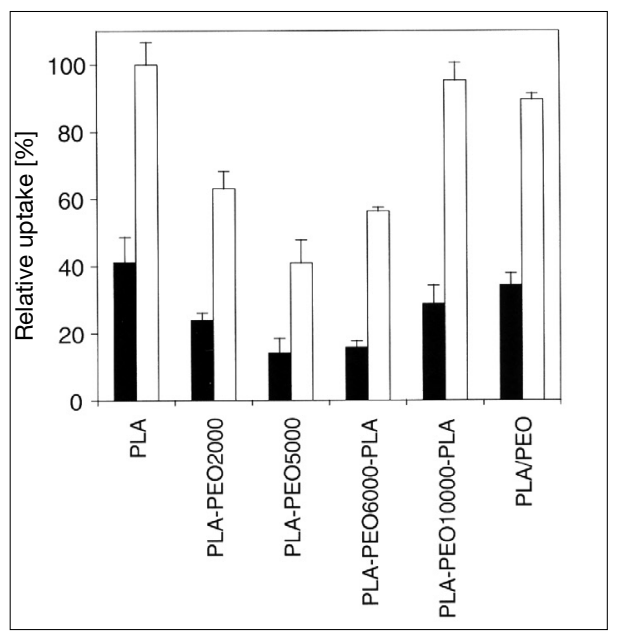

Fig. 8. Comparison between the relative uptake (cell-associated fluorescence) of plain PLA nanoparticles, PLA:PEO diblock and triblock copolymer nanoparticles and PLA-nanoparticles coated with adsorbed PEO 20000 in plasma ( $(\mathbf{)}$ and $(\square)[33]$ with short half-lives and for targeting drugs to specific organs or cells. In this respect, further development of new biomaterials and manufacturing methods for advanced dosage forms are needed. A better characterization of these drug carriers is also essential, together with the understanding of their fate in the organism.

\section{Abbreviations of Polymers}

EVAC: ethylene vinyl acetate copolymer PCL: poly( $\varepsilon$-caprolactone)

PEO: poly(oxyethylene) or PEG: polyethylene glycol

$\mathrm{P}(\mathrm{HB} / \mathrm{HV})$ : poly(hydroxybutyrate-

hydroxyvalerate)

POMEG: poly(tert-butyloxycarbonylmethyl glutamate)

L-PLA: poly(L-lactic acid)

DL-PLA: poly(DL-lactic acid)

PLGA: poly(DL-lactic acid-co-glycolic

acid)

PLA-MePEG: poly(DL-lactic acid)-

methoxypoly(ethylene glycol)

\section{Acknowledgments}

Thanks are expressed to other authors of the work presented in the article, in particular Professors R. Gurny, D. Quintanar-Guerrero, and J.-C. Leroux, as well as Dr. E. Alléman, F. Lescure, N. Follonier, C. Witschi, and F. De Jaeghere.

\section{Received: April 18, 2005}

[1] O.H. Chan, H.L. Schmid, L.A. Stilgenbauer, W. Howson, D.C. Horwell, B.H. Stewart, Pharm. Res. 1998, 15, 1012.

[2] J. Devane, Pharm. Technol. 1998, 22(11), 68.

[3] G. Walsh, Eur. J. Pharm. Sci. 2002, 15,135.

[4] H.-H. Gruenhagen, Pharm. Technol. Europe 1996, 8 (10), 22.

[5] J. Breitenbach, Eur. J. Pharm. Biopharm. 2002, 54, 107 .

[6] F. Zhang, J. W. McGinity, Pharm. Dev Technol. 1999, 4, 241.

[7] N. Follonier, E. Doelker, E.T. Cole, Drug Dev. Ind. Pharm. 1994, 20, 1323.

[8] N. Follonier, E. Doelker, E.T. Cole, J. Control. Rel. 1995, 36, 243.

[9] A.G. Sarraf, H. Tissot, P. Tissot, D. Alfonso, R. Gurny, E. Doelker, J. Appl. Polym. Sci. 2001, 81, 3124.

[10] A.G. Sarraf, F. Barja, L. Ouali, E.G. Sarraf, R. Gurny, E. Doelker, Proceed. Int. Symp. Control. Rel. Bioact. Mater. 2001, 28, 423.

[11] J.-C. Leroux, R. Cozens, J.L. Roesel, B. Galli, F. Kubel, E. Doelker, R. Gurny, J. Pharm. Sci. 1995, 84, 1387.

[12] J.-C. Leroux, R.M. Cozens, J.L. Roesel, B Galli, E. Doelker, R. Gurny, Pharm. Res. 1996, 13,485

[13] F. De Jaeghere, E. Allémann, F. Kubel, B Galli, R.M. Cozens, E. Doelker, R. Gurny,
J. Control. Rel. 2000, 68, 291.

[14] F. De Jaeghere, E. Allémann, E. Doelker, R. Gurny, AAPS PharmSci. 2001, 3, 1.

[15] F. De Jaeghere, E. Doelker, R. Gurny. in 'Encyclopedia of Controlled Drug Delivery', vol. 2. 'Nanoparticles', Ed. E. Mathiowitz, J. Wiley \& Sons, Inc, New York, 1999, 641.

[16] J.-C. Leroux, E. Allémann, E. Doelker, R. Gurny, Eur. J. Pharm. Biopharm. 1995 , $41,14$.

[17] D. Quintanar-Guerrero, H. Fessi, E. Allémann, E. Doelker, Int. J. Pharm. 1996, 143 , 133.

[18] S. Galindo-Rodriguez, E. Allémann, H. Fessi, E. Doelker, Pharm. Res. 2004, 21 , 1428.

[19] F. Lescure, Ph. D. thesis, University of Geneva, 1991.

[20] F. Lescure, R. Gurny, E. Doelker, J. Biomed. Mater. Res. 2003, 23, 1299.

[21] F. Lescure, R. Gurny, E. Doelker, J.M. Anderson, Biomaterials 1992, 13, 1009.

[22] F. De Jaeghere, E. Allémann, F. Kubel, B. Galli, R. Cozens, E. Doelker, R. Gurny, $J$. Control. Rel. 2000, 68, 291.

[23] C. Aftabrouchard, Ph. D. thesis, University of Geneva, 1994

[24] C. Witschi, E. Doelker, Int. J. Pharm. 1998, 171,1 .

[25] C. Witschi, E. Doelker, J. Control. Rel. 1998, 51, 327.

[26] U. Bilati, E. Allémann, E. Doelker, Pharm. Dev. Technol. 2003, 8,1

[27] U. Bilati, E. Allémann, E. Doelker, Eur. J. Pharm. Sci. 2005, 24, 67.

[28] U. Bilati, E. Allémann, E. Doelker, Controlled Release Society 31st Annual Meeting Transactions 2004, 513.

[29] U. Bilati, C. Pasquarello. G.L. Corthals, D.F. Hochstrasser, E. Allémann, E. Doelker, J. Pharm. Sci. 2005, 94, 688.

[30] J.-C. Leroux, P. Gravel, L. Balant, B. Volet, J. Biomed. Mater. Res. 1994, 28, 471.

[31] J.-C. Leroux, F. De Jeaghere, B. Anner, E. Doelker, R. Gurny, Life Sci. 1995, 57, 695.

[32] F. De Jaeghere, E. Allémann, J.-C. Leroux, W. Stevels, J. Feijen, E. Doelker, R. Gurny, Pharm. Res. 1999, 16, 859.

[33] F. De Jaeghere, E. Allémann, J. Feijen, T. Kissel, E. Doelker, R. Gurny, J. Drug Targeting 2000, 8, 143.

[34] C.A. Nguyen, E. Allémann, G. Schwach, E. Doelker, R. Gurny, Int. J. Pharm. 2003, 254, 69.

[35] C.A. Nguyen, E. Allémann, G. Schwach, E. Doelker, R. Gurny. Eur. J. Pharm. Sci. 2003 , 20, 217.

[36] E. Allémann, J. Rousseau, N. Brasseur, S.V. Kudrevich, K. Lewis, J.E. Van Lier, Int. J. Cancer 1996, 66, 821.

[37] J.-C. Leroux, E. Allémann, F. De Jaeghere, E. Doelker, R. Gurny, J. Control. Rel. 1996, 39, 339. 